Bødtker-Lund, D., Hansen, K. H., Haaland, G., Vagle, I. (2017). Endringsbehov i norsk yrkesopplæring? Elevers, lærlingers og yrkesfaglæreres erfaringer med yrkesopplæring i Vg1. Scandinavian Journal og Vocations in Development. http://dx.doi.org/10.7577/sjvd.2577

Fagfellevurdert artikkel

(Peer reviewed article)

\title{
Endringsbehov i norsk yrkesopplæring? \\ - Elevers, lærlingers og yrkesfaglæreres erfaringer med yrkesopplaring i Vg1
}

Likeverdige forfattere:

Daniel Bødtker-Lund

Institutt for Yrkesfaglærerutdanning, Høgskolen i Oslo og Akershus (HiOA)

daniel.bodtker-lund@hioa.no

Kari Henriette Hansen

Institutt for lærerutdanning, Norges teknisk-naturvitenskapelige universitet (NTNU)

kari.hansen@,ntnu.no

Grete Haaland

Institutt for Yrkesfaglærerutdanning, Høgskolen i Oslo og Akershus (HiOA)

Grete.haaland@hioa.no

Inger Vagle

Institutt for Yrkesfaglærerutdanning, Høgskolen i Oslo og Akershus (HiOA)

Inger.vagle@,hioa.no

Nøkkelord: Organisering av opplæringen, yrkesrelevans, læringsmiljø, medvirkning og demokrati. 


\section{Sammendrag}

Artikkelen belyser hvordan opplæringens innhold i Vg1 erfares av elever, lærlinger og lærere, som grunnlag for vurdering av endringsbehov i norsk yrkesopplæring. Problemstillingen artikkelen gir svar på er: Hvordan fungerer Vgl yrkesfaglig utdanningsprogram for elever med ulike yrkesvalg?

Bakgrunnen for studien artikkelen bygger på er at en strukturendring er på trappene i norsk yrkesopplæring. Kunnskapsdepartementet har brukt en rekke eksperter i forarbeidet, uten at elever og yrkesfaglærere har vært involvert i nevneverdig grad. Vi ønsker å bringe fram elevers og læreres stemmer.

Teoriforankringen er knyttet til forhold som har betydning for elevers motivasjon, mestring og læring, samt nasjonale føringer, mål og hensikt med yrkesopplæringen. Metodene i forskningsarbeidet er elektronisk spørreundersøkelse blant elever i Vg1 og Vg2, samt lærlinger i de yrkesfaglige utdanningsprogrammene og semistrukturerte intervjuer med yrkesfaglærere.

Et hovedfunn er at opplæringen i Vg1 ikke samsvarer med elevenes ulike læringsbehov, og heller ikke med de nasjonale føringene for yrkesopplæringen. Vg1 bør gjennomgå store endringer, basert på elevenes og lærernes erfaringer, for å sikre yrkesrelevant opplæring for elever med ulike utdanningsplaner og yrkesinteresser. 


\begin{abstract}
Need for change in the Norwegian Vocational education?

- Students, apprentices and vocational teachers experiences from basic year of vocational education
\end{abstract}

This article presents the students, apprentices and teachers point of view in relation to content of the vocational education programs. Their experiences lay as the foundation for answering the following research question; "How does the vocational education program support and prepare students heading for different professions?"

The motivation for this study is the ongoing change of structure within the Norwegian vocational education. The Ministry of education has involved several experts in this changing process, however, no students nor teachers have been included. This article will therefore bring forward students, apprentices and teachers voices, before the ministry of education make their decisions. Their experiences of the current education programs, are important as part of the foundation for the evaluation of a need for change.

The theoretical perspectives are related to conditions regarding students motivation, sense of accomplishment, ability to learn, as well as national guidelines and regulations, goals, and the overall purpose of the vocational education program. The research methods used (in the work) are electronic surveys among the vocational study's current first and second year students as well as apprentices within the specialized educational programs. It also includes semi structured interviews with profession specialized vocational teachers.

One key finding reveals that the current educational programs fail to meet the students individual learning needs, nor does it comply with national guidelines and regulations for the Norwegian vocational educations. The basic year works for some students and professions but not for others.

Based on the students and teachers experiences, there is a significant need to change the vocational education programs, to ensure the education is relevant for students who have different career plans and are heading for different professions.

Key Words: Organizing vocational education, vocational relevance, learning environment, participation, democracy 


\section{Innledning}

Artikkelen belyser hvordan opplæringens innhold i Vg1 blir erfart av elever, lærlinger og lærere. Studien er basert på elektronisk spørreundersøkelse blant elever i Vg1 og Vg2 yrkesfaglige utdanningsprogram og lærlinger i utvalgte lærefag. Lærernes erfaringer er basert på gruppeintervjuer. Funn fra undersøkelser og intervjuer drøftes mot aktuell motivasjons- og læringsteori og relateres deretter til nasjonale føringer for yrkesopplæringen.

Den norske fag- og yrkesopplæringen har de siste årene gjennomgått betydelige endringer (Reform 94; Kunnskapsløftet 2006 (Kunnskapsdepartementet, 2006); Deichman-Sørensen, 2015). Det ble dessuten annonsert nye endringer i 2016, som er planlagt satt i verk høsten 2019/2020. Endringene utløses særlig av frafall og bortvalg, lav kapasitet i bedriftsopplæringen samt kritikk fra ulike hold om at yrkesopplæringen ikke i tilstrekkelig grad ivaretar elevenes læringsbehov og bransjenes og samfunnets kompetansebehov (Hansen \& Haaland, 2015a).

Det er i dag store utfordringer i yrkesopplæringen knyttet til frafall og bortvalg, samt mangel på kvalitet og yrkesrelevans ${ }^{1}$ for mange elever ved de yrkesfaglige utdanningsprogrammene. I Reform 94 (R94) ble det satt et mål om at nitti prosent av elevene skulle gjennomføre videregående opplæring. Siden R94, da norsk ungdom fikk en lovfestet rett til treårig videregående opplæring, har frafallet og bortvalget vært stabilt. Lav kapasitet i bedriftsopplæringen og et stort misforhold mellom antall elever og avlagte, beståtte fagprøver som utløser endringer (Aarkrog \& Bang, 2013), synliggjør også utfordringene.

Yrkesopplæringen etter Kunnskapsløftet (LK06) er evaluert og sammenfattet i Meld. St. 20 (2012-2013). I tillegg er det foretatt flere ulike forskningsarbeider etter LK06 som viser at utfordringer knyttet til å oppnå yrkesrelevans for elever i Vg1 og brede Vg2 har vært store, og at "smakebitpedagogikk" og generell opplæring som ikke knyttes til elevenes interesser og yrkesvalg, har vært utbredt (Sund, 2005; Dahlback, Hansen, Haaland \& Sylte, 2011; Hansen \& Haaland, 2015a). Statistikk fra 1999 fram til i dag viser at ca. $70 \%$ har

\footnotetext{
${ }^{1}$ Yrkesrelevans: samsvar mellom innhold og arbeidsmåter i opplæringen og yrkes-/lærefagenes kompetansebehov

2 smakebitpedagogikk: hvor elevene blir introdusert for og må jobbe med mange ulike yrker i moduler gjennom hele skoleåret, selv om de i utgangspunktet har klare yrkesønsker når de starter i Vg1 (Dahlback et al., 2011; Meld. St. 20 (2012-2013); Hiim, 2013; Hansen \& Haaland, 2015a; Hansen, 2017).
} 
gjennomført videregående opplæring på yrkesfag i denne perioden innen fem år etter at de startet (Vogt 2017). Senere tall fra Stortingsmelding 20 (2012-2013) viser at det er 57\% av elevene på yrkesfag som fullfører innen fem år og at 26\% av elevene slutter. De siste tallene fra Statistisk sentralbyrå (SSB) viser at 59\% av elevene på yrkesfag gjennomfører i løpet av fem år (Statistisk sentralbyrå, 2017). Tallene er fra 2016. Tallene varierer noe fra utdanningsprogram til utdanningsprogram.

Kunnskapsdepartementets forslag til ny struktur er basert på et kunnskapsgrunnlag som innbefatter de ni faglige rådenes utviklingsredegjørelser, de fem yrkesfaglige utvalgenes forslag til endringer og Utdanningsdirektoratets forslag (Utdanningsdirektoratet, 2017a), basert på de nevnte utviklingsredegjørelsene og forslagene fra de yrkesfaglige utvalgene. Det som er felles for disse, er at elevenes og lærernes stemmer i svært liten eller ingen grad er representert og at vurdering av kvalitet på opplæringen ikke nevnes som grunnlag for endringsforslagene.

Vår motivasjon for og hensikten med denne artikkelen er å utvikle ny kunnskap om forhold som ligger bak tallene i de mange statistikkene knyttet til frafall og bortvalg fra SSB og andre forskningsmiljøer. I denne artikkelen viser vi analyse og resultat fra første del av en større studie. Forskningsdesignet for hele studien vises i figur 2 på side 10. Vi bringer her fram elevers, lærlingers og læreres stemmer i endringsprosessene og deres opplevelse av kvalitet i dagens yrkesopplæring. Kvalitet betyr her at alle elevene, både de elevene som har klare utdanningsplaner når de begynner i Vg1 og de som ikke har det, skal oppleve opplæringen som interessant, nyttig og relevant i forhold til utdannings-/yrkesinteresser, sett i lys av aktuell motivasjons- og læringsteori (Deci \& Ryan, 2000; Illeris, 2012; Skaalvik \& Skaalvik, 2013; Hansen \& Haaland, 2015a). Resultatet av forskningen, med hovedfokus på elevenes, lærlingenes og yrkesfaglærernes erfaringer med Vg1, skal spilles inn til partene i arbeidslivet, Utdanningsdirektoratet (Udir.) og Kunnskapsdepartementet (KD).

Artikkelen belyser følgende problemstilling: Hvordan fungerer Vgl yrkesfaglig utdanningsprogram for elever med ulike yrkesvalg? 


\section{Nasjonale føringer for yrkesopplæringen}

Nasjonale føringer og tolkninger av disse er basert på tidligere forskning (Dahl, Buland, Mordal \& Aaslid, 2012; Dahlback et al., 2011; Deichman-Sørensen, 2015; Hansen \& Haaland, 2015a, 2015b; Hiim, 2013; Aarkrog \& Bang, 2013). Nye NOUer og Meldinger til Stortinget inngår i tolkningsgrunnlaget (Meld. St. 20 (2012-2013); Meld. St. 28 (20152016); NOU 2015:8, 2015)

Fra innføringen av Reform 94 og fram til i dag er grunnlaget og nasjonale føringer for yrkesopplæringen så å si uendret. Forskjellen kan i grove trekk knyttes til at noe av det som var intensjoner i Reform 94 er forskriftsfestet i Kunnskapsløftet (LK06), som for eksempel innholdet i forskriften «Prinsipper for opplæringen». Det utdanningspolitiske grunnlaget for endringene som i dag er på gang i yrkesopplæringen, kan ifølge Kunnskapsdepartementet v/Dagfinn Hertzberg ${ }^{3}$ oppsummeres i tre punkter:

1. Relevans i forhold til arbeidslivets og samfunnets kompetansebehov, elevenes yrkesinteresser og tidligere erfaring

2. Konsistens, som betyr helhet og sammenheng i opplæringen fra begynnelse (Vg1) og fram til fag- og svennebrev

3. Barekraft som her betyr mulig tilbud for elever i skole og som lærlinger i bedrift

Samtidig er kompetansebegrepet videreutviklet til å innbefatte evne til refleksjon, egenvurdering og problemløsning, som samsvarer med framtidig kompetansebehov i henhold til for eksempel Ludvigsenutvalgets innstilling om fremtidens skole (NOU 2015:8, 2015) og KDs høringsutkast om ny struktur i yrkesopplæringen (Utdanningsdirektoratet, 2017a; Kunnskapsdepartementet, 2017). Kompetansedefinisjon for fagfornyelsen (Meld. St. 28, (2015-2016), 2015, s. 28): Kompetanse er å tilegne seg og anvende kunnskaper og ferdigheter til å mestre utfordringer og løse oppgaver $i$ kjente og ukjente sammenhenger og situasjoner. Kompetanse innebcerer forståelse og evne til refleksjon og kritisk tenkning.

Et uttrykt mål i fag- og yrkesopplæringen er å utdanne gode kvalifiserte fagfolk i tråd med samfunnets behov for kompetanse (Meld. St. 18 (2012-2013), 2012). Vi skal utdanne dyktige håndverkere, reflekterende praktikere og samfunnsdeltakere med høy yrkeskompetanse og danning (LK06; Utdanningsdirektoratet, 2017b). Skolen skal «både svare på arbeidslivets

\footnotetext{
${ }^{3}$ Foredrag ved Høgskolen i Oslo og Akershus 16.05.2017
} 
kortsiktige behov, tilpasse opplæringen til elevenes læreforutsetninger og legge til rette for at elevene skal utvikle en kompetanse som kan videreutvikles gjennom flere tiår i et arbeidsliv i endring» (Meld. St. 20 (2012-2013) s. 13), 2012). Illeris (1999) er opptatt av utdanningsstrategier som noe mer enn å kvalifisere seg for samfunnets og yrkenes nødvendige kvalifikasjonskrav. Forfatteren er opptatt av at utdanningen må realisere “dobbeltkvalifisering” og

...bidrage til en udvikling der sætter dem i stand til at overskue, tage stilling til og overskride denne kvalificering, giver rum for modstand, oprør, fællesskab, livsglæde og kreativitet, og dermed indgå $i$ et folkeligt modspil til de kræfter og interesser der er dominerende i det markedsstyrerende samfundet (Illeris, 1999, s. 14).

Hansen \& Haaland (2015a) skriver at det ikke er tilstrekkelig å utdanne eller kvalifisere for arbeidslivets og samfunnets nødvendige krav; yrkesopplæringen har et selvfølgelig ansvar for å stimulere elevene til å kunne utvikle seg som aktive og kritiske premissleverandører og deltakere for å videreutvikle yrkene og samfunnet - å kunne bidra til endring. For å oppnå dette må elevene ha tid til å øve på yrkesoppgavene. De må være gode håndverkere/ yrkesutøvere for å utvikle nødvendig analytisk kompetanse (Nilsen \& Haaland, 2013).

Fokus både i forskning og i den offentlige debatten har siden Reform 94 i all hovedsak vært på elevenes gjennomføring av videregående opplæring og i liten grad rettet mot kvalitet og innhold i yrkesopplæringen. Vår forskning har fokus på innhold og kvalitet og på hva som motiverer til mestring og læring for unge elever i Vg1. Vi ønsker å fremme elevers og læreres stemmer knyttet til innholdet i opplæringen, som grunnlag for å forstå hva som ligger bak tallene i de mange statistikker om gjennomføring og bortvalg.

\section{Motivasjon og læring i yrkesfag}

Motivasjons- og læringsteorien artikkelen bygger på, er tematisk bygd opp og strukturert i fire fokusområder som representerer hovedtemaene i spørreundersøkelsen blant elever og lærlinger og lærerintervjuene. Fokusområdene er sentrale i evalueringen av Kunnskapsløftet som er oppsummert i Melding til Stortinget nr. 20, På rett vei - Kvalitet og mangfold i fellesskolen (Meld. St. 20 (2012-2013), 2012). Valget av motivasjons- og læringsteori er forankret i tidligere forskning (Dahl, Buland, Mordal \& Aaslid, 2012; Dahlback et al., 2011; Deichman-Sørensen, 2015; Hansen \& Haaland, 2015a, 2015b; Hiim, 2013; Aarkrog \& Bang, 2013). 


\section{Relevant kompetanse for arbeidslivet og elevenes yrkesvalg}

Aarkrog og Bang (Aarkrog og Bang, 2013) diskuterer utfordringer med de brede utdanningsprogrammene hvor elevene må arbeide med mange ulike yrkesmoduler i skolen uavhengig av deres yrkesinteresser. Forfatterne fremhever betydningen av at yrkesrelevant praksis i spesifikke yrker kan være et viktig pedagogisk verktøy for bedre å ivareta motivasjon for og lyst til å lære. Dette betyr en yrkesdidaktisk tilnærming til opplæringen, hvor elevene arbeider med mål/temaer på ulike måter, forankret i det spesifikke yrket elevene utdanner seg til, eller er interessert i (Hansen \& Haaland, 2015a, 2015b). Yrkesforankring innbefatter tolkning av loereplaner og valg av arbeidsoppgaver som passer til elevenes interesser og eventuelle yrkesvalg.

Skaalvik og Skaalvik (Skaalvik \& Skaalvik, 2013) mener den vanligste måten motivasjonsteoretikere definerer motivasjon på, er "en situasjonsbestemt tilstand som påvirkes av verdier, erfaringer, selvvurdering og livserfaring” (s. 136). Forfatterne diskuterer hva som må ivaretas i skolen og undervisningen for at elevene skal kunne bevare autonom motivasjon for skolearbeidet. De viser til Deci og Ryans (2000) teori om indre motivasjon, hvor tre grunnleggende psykologiske behov må ivaretas: 1) tilhørighet, 2) kompetanse og 3) selvbestemmelse, og mener at av disse tre behovene legger Deci og Ryan størst vekt på selvbestemmelse. Teorien gir støtte til flere av de nasjonale føringene for yrkesopplæringen, blant annet kravet om elevmedvirkning og demokrati som læringsstrategi. Det er et uttrykt mål i Læreplanverket for Kunnskapsløftet (LK06) og flere andre styrings- og grunnlagsdokumenter for yrkesopplæringen at elever skal utvikle danning, gryende yrkeskompetanse og yrkesstolthet fra første dag (Kunnskapsdepartementet 2006, Meld. St. 20 (2012-2013), 2012). Utvikling av yrkeskompetanse og yrkesstolthet krever at elevene arbeider med yrker de er interessert i. En forutsetning for yrkesrelevant opplæring er at elevene selv kan bestemme hvilket/hvilke yrker de vil rette læringsarbeidet mot. Opplæringen skal være relevant for de yrkene elevene utdanner seg til og resultere i en kompetanse i tråd med dagens og framtidige krav i arbeidslivet.

\section{Tilpasset opplæring til elevenes læreforutsetninger}

John Dewey hevder det er av avgjørende betydning at oppdrageren, som for eksempel kan være foreldre, lærer eller leder, hele tiden observerer individets interesser nøye (Dewey, 2000). Ifølge Dewey vil en undertrykking av individets interesser sette den voksne, eller oppdrageren, foran den lærende og dermed svekke den lærendes intellektuelle nysgjerrighet 
og oppvakthet, kvele initiativ og drepe interesser.

Følelse av kompetanse krever at undervisningen og arbeidsoppgavene er tilpasset elevenes læreforutsetninger, ferdigheter og behov (Skaalvik \& Skaalvik, 2013, s. 148). Vår tolkning av begrepet følelse av er knyttet til elevenes opplevelse av mening og mestring i arbeid med ulike læringsoppgaver. Arbeidsoppgavene må tilpasses til den enkelte elevs mulighet til å lære, og eleven må få hjelp og veiledning i det daglige arbeidet i klasserom og verksted. Da alle yrkesfagelever starter yrkesopplæring i brede Vg1, har de behov for å lære ulike ting, basert på interesser og eventuelle yrkes-/utdanningsplaner.

En tilpasset opplcering til elevenes loereforutsetninger handler i yrkesopplæringen blant annet om at utdanningens innhold bygger på elevenes ulike yrkesønsker, yrkesdrømmer og behov, en forutsetning for utvikling av drivkraft for læring og mestring. Nyere forskning viser at opplæringens innhold ofte ikke oppleves relevant og interessant for alle elevene, spesielt for de elevene som har gjort bevisste yrkesvalg før de begynner i videregående skole og ikke får mulighet til å jobbe målrettet med dette fra første dag (Dahlback et al., 2011; Hansen \& Haaland, 2015b; Hiim, 2013). Hvis elevene ikke får mulighet til utviklet følelse av kompetanse, kan dette føre til mangel på mestringsopplevelse og læring.

Tilpasset opplæring er et grunnleggende prinsipp i de nasjonale føringene som gjelder alle elevene (Kunnskapsdepartementet, 2006). Opplæringen skal tilpasses elevenes forutsetninger knyttet til 1) kompetanse, 2) interesser og yrkesplaner og 3) eventuelle andre spesielle læringsbehov.

Figur 1 viser en modell som illustrerer bredden og mangesidigheten i læring (Illeris, 2012). Modellen viser forholdet mellom et meningsfullt innhold i opplæringen og utvikling av drivkraft eller motivasjon for læring. Her synliggjøres det Illeris beskriver som læringenes tre dimensjoner og to prosesser. De tre dimensjoner i læring benevner han som innhold, drivkraft og samspill. Hans grunnleggende tese er «at all læring involverer disse tre dimensjonene, og at alle tre dimensjonene alltid må tas med i betraktning hvis en forståelse eller analyse av en læringssituasjon eller et læringsforløp skal være fyllestgjørende» (Illeris, 2012, s. 42). De to prosessene i læring omtaler han som tilegnelsesprosessen og samspillsprosessen. Tilegnelsesprosessen er en indre mental tilegnelse og bearbeidelse av de 
nye impulsene til den lærende, og samspillsprosessen er prosessen basert på samspillet mellom individet (eleven) og dets omgivelser. Begge prosessene skjer innenfor rammene av sosial og samfunnsmessig kontekst (2012).

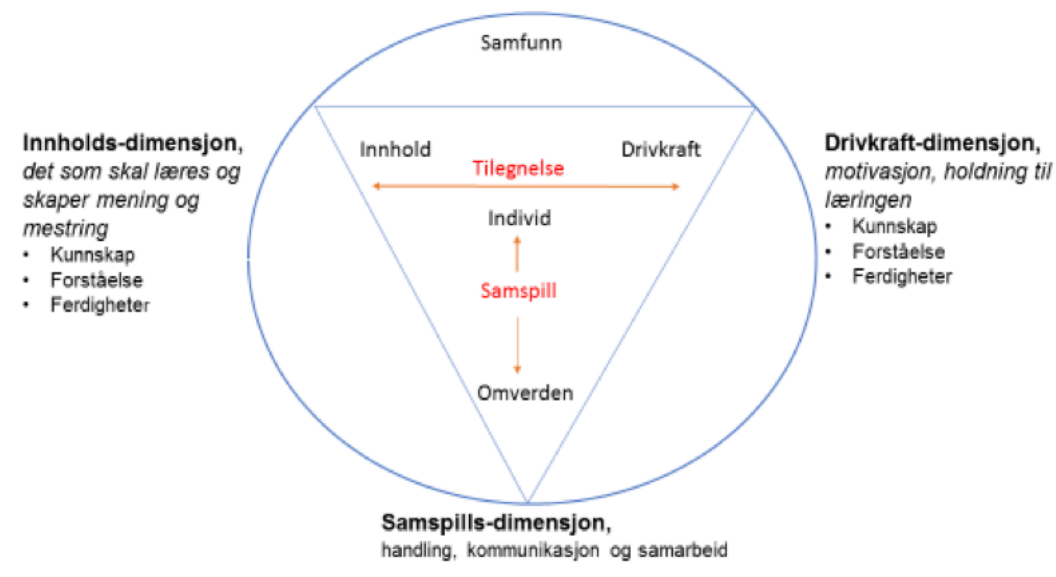

Figur 1 Modell som viser laeringenes fundamentale prosesser (Illeris, 2012)

Dewey er opptatt av at det viktigste med oppdragelsen var å forberede for intelligent deltakelse i et demokratisk levesett og at deltakelse og medvirkning er en forutsetning for læring (Dewey, 2000). Det utfordrer «det skapende mennesket» i læreplanens generelle del og den lærendes evne til å søke mening, velge, begrunne, gjennomføre, vurdere og lære av eget arbeid, som grunnlag for utvikling av selvvalgt identitet og læringskompetanse (Utdanningsdirektoratet, 2017).

Den enkelte elevens forutsetninger brukes i noen sammenhenger om elevenes ferdigheter i fag - det vil si deres kompetansenivå. I andre sammenhenger, og spesielt i yrkesopplæringen hvor mange av elevene har en spesifikk yrkesinteresse, betyr det både kompetanse og interesser, med bakgrunn i en forståelse om at det er interesse som stimulerer og driver nysgjerrighet og læring (Dewey, 2000). Dewey er kritisk til den tradisjonelle bokskolen, og hans erfaringsfilosofi var kritisk til ytre autoritet og fastlagte mål. Erfaringsfilosofien betinger handlingsrom i læreplanene og i elevenes valg av læringsarbeid, dersom tilpasset opplæring skal være mulig og læring skal skje (Dewey, 2000). I dokumentet «Prinsipper for opplæringen» beskrives føringer knyttet til arbeidsmåter, elevmedvirkning og tilpasset opplæring (Utdanningsdirektoratet, 2006). 


\section{En skolehverdag preget av elevmedvirkning og elevinnflytelse}

De interesser og eventuelle utdanningsplaner den enkelte eleven møter utdanningen med og elevenes medvirkning og innflytelse over valg av læringsarbeid, vil i denne sammenhengen kunne være et viktig forankringspunkt for å stimulere drivkraft i arbeid og læring og for å stimulere nysgjerrighet for nye fagområder (Dewey, 2000). Dewey er opptatt av at å forberede barn og ungdom på et framtidig liv, innebærer å gi dem selvbestemmelse (Dewey, 2000; Sund, 2005).

Behov for selvbestemmelse omhandler ifølge Skaalvik og Skaalvik elevens valgmuligheter både til innhold og arbeidsformer i skolen (2013, s. 149). I Vg1 og brede Vg2 i yrkesfaglige utdanningsprogram kan elevenes valgmuligheter ses i sammenheng med behov for selvbestemmelse i valg av yrke og yrkesrelevant læringsarbeid. Nyere forskning og evaluering av LK06 viser at av mange skoleeiere, skoleledere og lærere blir læreplanene i de brede utdanningsprogrammene tolket slik at elevene skal ha introduksjon i flere yrker, spesielt det første året. Mange elever blir det første året pålagt en «smakebitpedagogikk».

Behovet for tilhørighet viser nødvendigheten av at skolen og lærerne skaper et trygt og inkluderende arbeids- og læringsmiljø, hvor alle elevene blir sett og respektert (Skaalvik \& Skaalvik, 2013). Dette gjelder all utdanning. I yrkesopplæring handler dette om at arbeidsoppgavene har et innhold som er relevant og interessant for den enkelte eleven, som er en forutsetning for mestring, og at elevene føler og opplever seg som reelle bidragsytere $\mathrm{i}$ både et faglig og sosialt fellesskap i klassen. Tidligere forskning på yrkesopplæring viser at elevenes forventninger om mestring av arbeidsoppgaver er en viktig kilde til motivasjon og innsats (Hansen \& Haaland, 2015b).

I Dale og Wærness (Dale og Wærness, 2003) understrekes det at utdanning og arbeidsliv skal ha plass for alle. I «Prinsipper for opplæring» presiseres det at elevene skal ha innflytelse på eget læringsarbeid, elevmedvirkning, på en slik måte at det sikrer opplevelse av mening og relevans i forhold til yrkesinteresser og eventuelle utdaningsplaner. Demokrati som læringsstrategi og styringsform er her sentralt og viktig for elevenes motivasjon og læring. 


\section{Yrkesretting og sammenheng mellom nivåene i yrkesopplæringen}

Deci og Ryan (Deci \& Ryan, 2000) og Illeris (Illeris, 2012) er opptatt av at de som skal lære, må ha et mestringsbehov. Mestringsbehovet kan knyttes til elevenes behov for helhet og sammenheng mellom skolefagene på hvert nivå i yrkesopplæringen, sammenhengen mellom Vg1, Vg2 og Vg3/bedriftsopplæringen og det utdannings- og eventuelt yrkesmålet elevene har. Dahlback et al. (2011) viser i sin forskning betydningen av yrkesretting og yrkesrelevans i opplæringen for elevenes motivasjon og engasjement. Det samme viser Hansen og Haaland i sin artikkel om kvalitet i yrkesopplæringen (Hansen \& Haaland, 2015a).

Hovedmodellen i dagens yrkesopplæring er to år i skole og to år som lærlinger i virksomheter/bedrift. I Stortingsmelding nr. 30 (2003-2004) presiseres det at det bør være en tydelig sammenheng mellom nivåene i fag- og yrkesopplæringen, mellom Vg1, Vg2 og Vg3/opplæring i bedrift. Det skal samtidig være helhet og sammenheng mellom skolefagene, programfag $(\mathrm{PF})$, fellesfag $(\mathrm{FF})$ og yrkesfaglig fordypning (YFF) på hvert nivå i yrkesopplæringen. Forskningsinstitusjonen SINTEF fulgte innføringen og gjennomføringen av Kunnskapsløftet (LK06) gjennom flere år. Studiene viser at en sentral faktor for å heve kvaliteten i fag- og yrkesopplæringen, er et helhetlig utdanningsløp fra ungdomsskolen gjennom videregående skole og læretid fram til fag- og svenneprøve (Dahl, Buland, Mordal \& Aaslid, 2012). "Etter syv år med skolereformen fremstår opplæringen for mange, både elever og lærlinger fortsatt som lite helhetlig” (Dahl et al., 2012, s. 7). Annen aktuell forskning tyder på at dette inntrykket ikke har endret seg nevneverdig siden 2012 (Meld. St. 20 (2012-2013), 2012; Hansen \& Haaland, 2015a).

\section{Metode}

I denne studien inngår både kvalitative og kvantitative metoder. Den kvalitative delen har en flermetodisk fenomenologisk forskningstilnærming (Postholm, 2010). Fenomenologisk forskning handler om å finne den sentrale underliggende meningen eller essensen i en opplevd erfaring (Postholm, 2010).

Fire fylker deltok i forskningsarbeidet. I den elektroniske spørreundersøkelsen deltok 2984 elever fra Vg1 og Vg2, og fra samtlige utdanningsprogram: Bygg- og anleggsteknikk (BA), Design og håndverk (DH), Teknikk og industriell produksjon (TIP), Restaurant og matfag 
(RM), Helse- og oppvekstfag (HO), Elektrofag (EL) Naturbruk (NA) og Service og samferdsel (SS). I tillegg har 384 lærlinger innen programområdene RM, HO, BA og DH deltatt i undersøkelsen. En prestudie av spørreundersøkelsen ble gjennomført med elever som gikk på Vg1, yrkesfag. Det kom inn viktige innspill som førte til endringer og presiseringer som hjelp til å kunne publisere en pålitelig spørreundersøkelse (Postholm \& Jacobsen, 2012).

Lime Survey ble brukt som verktøy for den elektroniske spørreundersøkelsen.

Spørreundersøkelsen ble utformet med både kvantitative og kvalitative spørsmål, spørsmål med svaralternativer og åpne spørsmål som ble besvart med beskrivende og reflekterende tekst. I den innledende delen av spørreundersøkelsen redegjorde vi for bakgrunn og hensikt og for at besvarelsen var frivillig og anonym.

Forskningen innbefatter fem semistrukturerte gruppeintervjuer med et strategisk utvalg av til sammen 28 yrkesfaglærere fordelt på samtlige utdanningsprogram, utenom naturbruk (Kvale \& Brinkmann, 2017). Lærerne kom fra utvalgte skoler i fylkene hvor spørreundersøkelsen med elevene ble gjennomført. To eller flere forskere deltok ved alle intervjuene, bortsett fra ett.

Intervjuene omhandlet de samme temaene som i spørreundersøkelsen (Postholm \& Jacobsen, 2012). Spørsmålene var ikke detaljert utformet, men fungerte som en tematisk guide som hjelp til fremdriften underveis i intervjuprosessen (Kvale \& Brinkmann, 2017). Figuren nedenfor viser en skjematisk oversikt over det helhetlige forskningsdesignet. 
Studien denne artikkelen belyser, er basert på forskningsaktivitetene i de lysgrå rutene i figur 2.

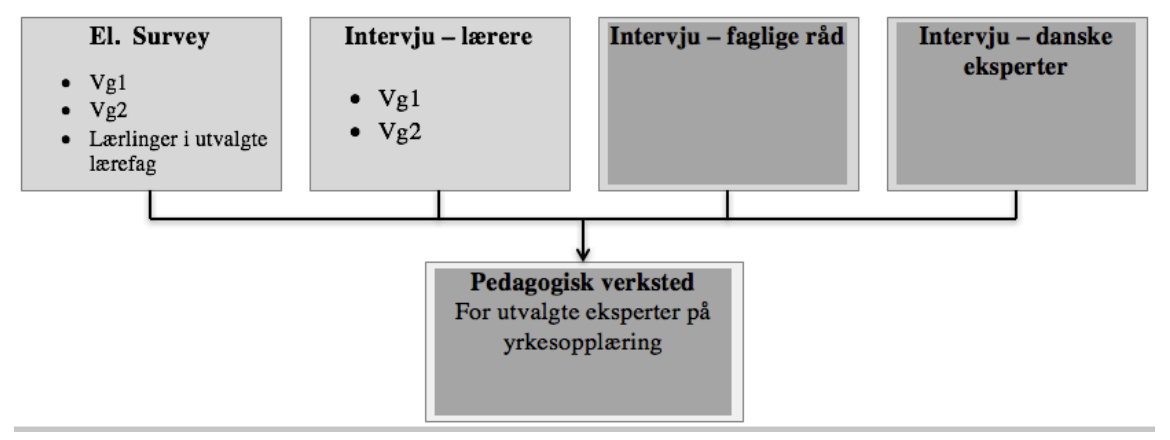

Figur 2 Forskningsdesign

Spørsmålene som inngikk i den elektroniske spørreundersøkelsen og intervjuene, omhandlet temaene organisering av opplceringen, yrkesrelevans, laringsmiljø, medvirkning og demokrati.

\section{Analyse av data}

I den kvalitative delen av spørreundersøkelsen som var gjort med elevene, fordelte vi elevutsagn mellom oss, men gjennomførte analysen av det totale datamaterialet i fellesskap. For å finne mønster og redusere materialet slik at det ble oversiktlig, håndterlig og presentabelt (Postholm, 2010; Kvale \& Brinkmann, 2017), fulgte vi fremgangsmåten ved at vi først leste grundig gjennom elevenes utsagn og fortettet teksten. Vi søkte etter meningsmønstre og likheter som grunnlag for kategorisering. De foreløpige hovedkategoriene som utviklet seg i analysearbeidet var: 1) Arbeids- og loeringsmiljø, 2) Faglige forventninger,3) Interessant/meningsfullt og 4) Rammer som hadde betydning. Disse hovedkategoriene ble brukt som et videre grunnlag for utvikling av intervjuguiden med lærere.

\section{Etikk, validitet og reliabilitet}

Studien er i sin helhet meldt inn til Norsk samfunnsvitenskapelig datatjeneste (NSD) og gjennomført i henhold til deres retningslinjer. Studien er godkjent med prosjektnummer 43139.

Forskningsetiske prinsipper ble fulgt gjennom studien (Kvale \& Brinkmann, 2017).

Begrepene validitet og overførbarhet handler om å gjøre rede for og sikre at undersøkelsen er 
troverdig og at funn som presenteres er til å stole på (Malterud, 2006). Funnene i forskningsarbeidene ses i lys av våre erfaringer fra yrkesutdanning i videregående skole og $\mathrm{i}$ bedrift, erfaringer som fagarbeidere i næringslivet innen elektrofag, restaurant- og matfag og design- og håndverksfag. Forskerteamet har kompetanse i statistikk, kvalitativ forskning/aksjonsforskning i yrkesfagopplæring og høyere profesjonsutdanning i pedagogikk og yrkesdidaktikk som lærere ved praktisk-pedagogisk utdanning (PPU) og treårig yrkesfaglærerutdanning (YFL) i en årrekke.

I den innledende delen av den elektroniske spørreundersøkelsen med elevene og lærlingene redegjorde vi for bakgrunn og hensikt, og at besvarelsen var anonym. I ettertid ser vi at det hadde vært en styrke for studien å ha gjennomført én-til-én-intervjuer med noen av elevene og lærlingene etter spørreundersøkelsen. Dette kunne gitt fyldige og detaljerte beskrivelser av deres forståelse, erfaringer, oppfatninger, meninger og holdninger knyttet til sentrale begreper og for begrunnelser for deres opplevelser (Johannessen, Tufte \& Christoffersen, 2016). Alle lærerne vi intervjuet, samtykket skriftlig, og det ble gjort lydopptak av intervjuene. Samtlige intervjuer med lærerne er transkribert og anonymisert. Når studien er ferdigstilt, blir alle rådata makulert.

\section{Resultater}

Funn og resultater knyttes til hvordan opplæringen i Vg1 erfares av elever, lærlinger og lærere. Resultatene presenteres og drøftes, og er strukturert under overskrifter som representerer hovedfunn i studien.

\section{Elevenes og lærlingenes forventninger og utdanningsplaner}

Elevene og lærlingene ble spurt om hvilke forventninger og utdanningsplaner de hadde da de begynte i Vg1. Figur 3 viser analyse av elevenes og lærlingenes kvalitative beskrivelser. Kategoriene er basert på elevenes beskrivelser av hva som var viktig for at kvaliteten på opplæringen skulle være god. 


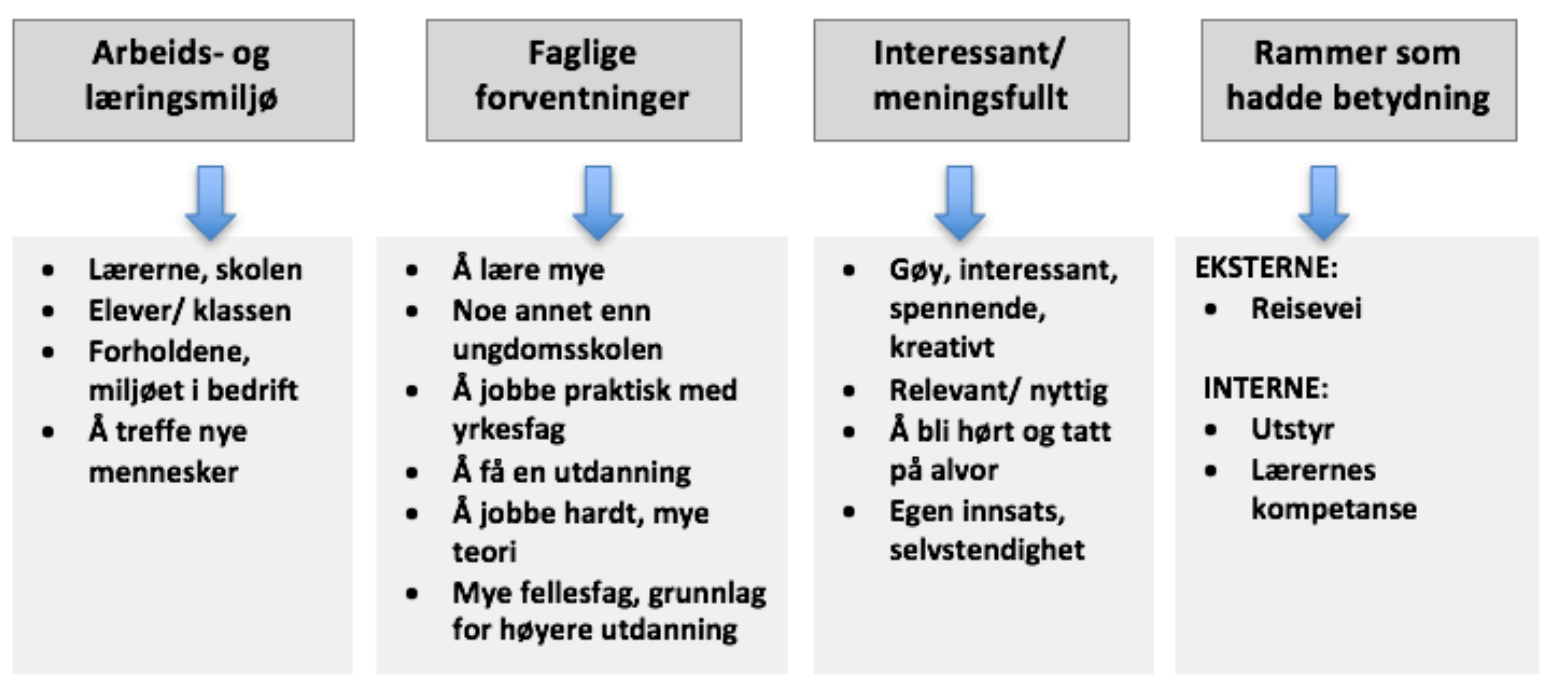

Figur 3 Elevenes forventninger til opploringen i VgI

Kort oppsummert viser funnene at elevenes kriterier for vurdering av kvalitet $\mathrm{i}$ yrkesopplæringen, kan sammenfattes i fire hovedpunkter, som i hovedsak også støttes av yrkesfaglærerne. Disse kriteriene er et resultat av analysen som ble gjort gjennom kategorisering av elevenes og lærlingenes kvalitative beskrivelser:

1. Opplæringen må oppleves relevant for det yrket de utdanner seg til.

2. Elevene må bli sett, hørt og tatt på alvor angående sine læringsbehov og utdanningsplaner.

3. Lærere må være gode og oppdatert i faget sitt, og kompetanse innen det yrkesfaget elevene utdanner seg til må være tilgjengelig.

4. Klasse-/læringsmiljøet må være godt.

Seksti prosent av elevene hadde bestemt seg for et bestemt yrke når de begynte i Vg1. Både de elevene som hadde bestemt seg for et spesifikt yrke og de som ikke hadde det, hadde i hovedsak store faglige og sosiale forventninger til opplæringen.

\section{Elever og lærlingers opplevelse av hvordan opplæringen i Vg1 var tilpasset deres yrkesvalg}

I tråd med tidligere forskning (Dahlback, et al., 2011; Hansen, 2017; Hansen \& Haaland 2015a, 2015b; Sund, 2005; Aarkrog \& Bang, 2013) viser funnene også i denne undersøkelsen at elevene i de ulike Vg1 i stor grad gjør de samme oppgavene, uavhengig av hvilket yrke de utdanner seg til. Funnene viser at for en stor del av elevene, er innholdet og arbeidsoppgavene i Vg1 yrkesrelaterte, men ikke nødvendigvis relatert til yrkene elevene 
utdanner seg til. Funnene viser også at innholdet for mange elever er knyttet til en form for basis- eller generell opplæring og ikke til yrkesrelatert opplæring, begrunnet $\mathrm{i}$ at det er et relevant grunnlag for utdanning til mange ulike yrker. Opplæringen er i svært liten grad rettet mot de konkrete yrkene elevene utdanner seg til.

Elever og lærlinger ble spurt om hvordan de opplevde innhold og arbeidsmåter i Vg1 relatert til det yrket de utdanner seg til eller er interessert i. Spørsmålet hadde svaralternativer og plass for beskrivelse og konkretisering med egne ord av svaralternativet de valgte.

Tabell 1. Lærlingenes svar på hvordan de opplever Vg1 med utgangspunkt i de ulike yrkene de utdanner seg til.

\begin{tabular}{lccc}
\hline Yrke/ Lærefag & $\begin{array}{c}\text { Utd. } \\
\text { program }\end{array}$ & $\begin{array}{c}\text { IKKE eller LITT } \\
\text { relevante programfag } \\
\text { for lærefaget i } \%\end{array}$ & $\begin{array}{c}\text { GANSKE eller SV ART } \\
\text { relevante programfag for } \\
\text { lærefaget i \% }\end{array}$ \\
\hline Anleggsgartnere & NA & 50 & 50 \\
Barne- og ungdomsarbeider & HO & 44 & 56 \\
Bilmekaniker & TIP & 58 & 42 \\
Blomsterdekoratør & DH & 50 & 50 \\
Dataelektroniker & EL & 100 & 0 \\
Elektriker & EL & 36 & 64 \\
Fotograf & MK & 50 & 50 \\
Frisør & DH & 71 & 29 \\
Helsefagarbeider & HO & 33 & 67 \\
Industrimekaniker & TIP & 42 & 58 \\
Kokk & RM & 20 & 80 \\
Konditor & RM & 100 & 0 \\
Logistikkarbeider & SS & 87 & 13 \\
Mediegrafiker & MK & 25 & 75 \\
Resepsjonist & SS & 50 & 50 \\
Rørlegger & BA & 50 & 50 \\
Tømrer & BA & 56 & 44 \\
SUM & Alle & 48 & 52 \\
\hline
\end{tabular}

Tabell 1 viser stor variasjon i lærlingenes opplevelse av hvor godt opplæringen passer til det yrket de utdanner seg til. Variasjonen er ikke knyttet til om utdanningsprogrammene er brede eller smale eller om lærefagene er store eller små. Årsaken til variasjonen kan kanskje knyttes til tilgjengelig lærerkompetanse, mangel på differensiering og yrkesdidaktisk tilnærming. En BA-lærer beskriver hvordan de organiserer opplæringen i Vg1: 
I programfagene rullerer vi, 6 uker på hver plass. Hos oss må elevene gjennom hele greia [...] men jeg har ikke tro på det. Når elevene har bestemt seg, må de få mulighet til å jobbe med selvvalgt yrke (Lærer, BA).

Elevene gjør stort sett de samme arbeidsoppgavene uavhengig av hva de ønsker å utdanne seg til. Manglende utstyr og tilgjengelighet til relevant arbeidsliv synes også å ha betydning. Lærlingene i for eksempel frisør-, dataelektroniker, logistikk- og konditorfaget opplever opplæringen som svært lite relevant for sine lærefag, mens lærlingene i kokk-, helsefagarbeider-, mediegrafiker- og elektrikerfaget er de som opplever Vg1 som mest yrkesrelevant.

Elevene i Vg1 ble spurt om hvor stor andel av tiden i FPF og YFF de opplevde å jobbe med oppgaver relatert til det yrket de utdanner seg til. Tabellen nedenfor viser at elevene opplever både FPF og YFF i Vg1 som forholdsvis lite relevant i forhold til eget yrkesvalg. Tabellen viser også at noen elever opplever at de jobber mindre av tiden i YFF relatert til sitt yrkesvalg enn i FPF.

Tabell 2. Andel av tiden i YFF og i felles programfag elevene opplever å jobbe mot eget yrkesvalg

\begin{tabular}{|c|c|c|c|}
\hline FAG & $\begin{array}{l}25 \% \text { av tiden } \\
\text { eller mindre }\end{array}$ & $50 \%$ av tiden & $\begin{array}{l}75 \% \text { av tiden eller } \\
\text { mer }\end{array}$ \\
\hline Yrkesfaglig fordypning (YFF) & $32 \%$ av elevene & $41 \%$ av elevene & $27 \%$ av elevene \\
\hline Felles programfag (FPF) & $33 \%$ av elevene & $37 \%$ av elevene & $30 \%$ av elevene \\
\hline
\end{tabular}

En tredel av elevene opplever å jobbe $25 \%$ eller mindre rettet mot eget yrkesvalg i begge fagene, men mindre enn en tredel av elevene opplever å jobbe mot eget yrkesfag i $75 \%$ eller mer. Dette gjelder både FPF og YFF. I HO er mange av elevene ute i praksis i tre ulike yrker. De synes å være ute i praksis i de samme yrkene, som ikke nødvendigvis innbefatter det yrket elevene utdanner seg til. Det kan bety at elevene ikke har innflytelse på hvilket yrke de skal fordype seg i, eller at det ikke er like lett å finne relevant arbeidsplass for alle yrkene i HO.

I BA jobber de fleste elevene mye mot tømrerfaget, uavhengig av hva de utdanner seg til. Siden de fleste elevene har planer om å bli tømrere, kan det ha betydning for at mange i BA opplever opplæringen som relevant i FPF. Det samme gjelder på RM, hvor de fleste vil utdanne seg til kokker, og innholdet i Vg1 er i stor grad rettet mot kokkfaget for alle elevene. 
Det er stor variasjon i bruk av ulike læringsarenaer i Yrkesfaglig fordypning (YFF) mellom de ulike utdanningsprogrammene som tabell 3 viser.

Tabell 3 viser hvor stor andel av elevene som er i bedrift, klasserom og skoleverksted i Yrkesfaglig fordypning, Vg1. $14 \%$ av elevene har svart «Vet ikke» eller blankt på dette spørsmålet. Disse elevene er ikke med i tabellen.

Tabell 3. Ulike laringsarenaer i Yrkesfaglig fordypning (YFF)

\begin{tabular}{lcccc}
\hline & $\begin{array}{l}\text { Totalt ant. } \\
\text { Elever som } \\
\text { har svart }\end{array}$ & $\begin{array}{l}\text { \%-andel av } \\
\text { elever i } \\
\text { bedrift }\end{array}$ & $\begin{array}{l}\text { \%-andel av } \\
\text { elever i } \\
\text { klasserommet }\end{array}$ & $\begin{array}{l}\text { \%-andel av } \\
\text { elever i } \\
\text { skoleverksted }\end{array}$ \\
\hline Bygg- og anleggsteknikk (BA) & 123 & 46 & 10 & 40 \\
Design og håndverk (DH) & 93 & 36 & 29 & 23 \\
Elektrofag (EL) & 324 & 10 & 47 & 40 \\
Helse- og oppvekstfag (HO) & 270 & 60 & 28 & 5 \\
Medier og kommunikasjon (MK) & 61 & 18 & 59 & 8 \\
Naturbruk (NA) & 69 & 44 & 12 & 29 \\
Restaurant- og matfag (RM) & 98 & 11 & 7 & 77 \\
Service og samferdsel (SS) & 116 & 65 & 30 & 3 \\
Teknikk og industriell produksjon (TP) & 312 & 28 & 7 & 59 \\
\hline
\end{tabular}

I utdanningsprogrammene Elektro (EL) og Restaurant og matfag (RM) er de fleste elevene på skolen i Yrkesfaglig fordypning (YFF), mens elevene i Helse- og oppvekstfag (HO) og Service og samferdsel (SS) er mest ute i yrkespraksis i bedrift/offentlige virksomheter. Lærerne begrunner dette på ulik måter:

Vi velger å ha elevene på skolen i YFF for å ha kontroll over det faglige innholdet. Sender vi dem ut i arbeidslivet, blir de ofte stående med ensformige og enkle arbeidsoppgaver uten særlig stort læringsutbytte (Lærer, Vg1 RM)

Ja, på service og samferdsel har vi utplassering 1 dag i uken, det er vi nødt til å ha, hvis ikke mister vi dem. Vi er nødt til å ha det avbrekket (Lærer, Service og samferdsel (SS)).

En lærer vi intervjuet fra Teknikk og industriell produksjon (TIP), forteller at YFF i bedrift en dag i uken har bidratt til økt motivasjon og mindre fravær.

Vi har elever som ikke fungerer eller har adferdsproblemer her på skolen, men som er helt sånn supre ut i bedrift. Møter helt presis, gjør en kjempejobb ute i bedrift (Lærer, TIP). 
En TIP-lærer fra en annen skole ønsker ikke utplassering i bedrift i YFF i Vg1 fordi «da blokkerer vi tilgangen til Vg2 elevene» (Lærer, TIP).

Funn fra undersøkelsen viser at 60 prosent av elevene hadde bestemt seg for utdanning til et spesifikt yrke før de startet på Vg1, og at de på slutten av VG1 hadde det samme yrket som mål. Det betyr at de elevene som har endret yrkesvalg i løpet av Vg1, inngår i de 40 prosentene som ikke hadde bestemt seg for yrke før $\mathrm{Vg} 1$.

Mange elever er lite interessert i det som foregår i programfagene, noe som kan knyttes til deres svar som viser manglende opplevelse av relevans. Andelen av elever som erfarte opplæringen som ganske, eller veldig interessert, var som følger: BA (61\%) og NA (59\%), HO (35\%) og SS (20\%). Selv på BA, og NA, hvor det var flest elever som erfarte opplæringen som ganske, eller svært interessant, var tallene lave.

Mange elever har liten innflytelse på eget læringsarbeid og ønsker å få velge mer. De opplever å ikke bli hørt, sett og tatt på alvor. Samtidig opplever mange elever det som demotiverende å jobbe med yrker de ikke er interesserte i, og å ikke forstå hva de skal bruke kunnskapen til i det yrket de utdanner seg til.

Når vi ser elevenes yrkesvalg og de arbeidsoppgavene elevene gjorde i Vg1, er det tydelig at opplæringen ikke er lagt opp til å passe til de yrkene elevene utdanner seg til, men at det er andre forhold som bestemmer innholdet $\mathrm{V}$ Vg1 ved de ulike utdanningsprogrammene.

Elever, lærlinger og lærere opplever i stor grad at opplæringen i Vg1 ikke er relevant for det yrket elevene utdanner seg til. Dette gjelder alle de yrkesfaglige utdanningsprogrammene og gjelder spesielt for de elever som har bestemt seg for et spesifikt yrke. En lærer ved BA sier det på denne måten:

Viktig å ta vare på motiverte Vg1 elever som kommer og skal bli for eksempel rørlegger. I dag må de være med [...] på mange, mange, mange fag og da kan det demotivere en i utgangspunktet motivert elev. Så dette er viktig å ta tak i på Vg1 (Lærer, BA).

Dataelektroniker er eksempel på ett av de yrkene der elever og lærere opplever opplæringen på Vg1 elektro som lite eller ikke relevant for. Mange av elevene har planlagt påbygg etter 
Vg2 (se tabell 4 og 5) og videre utdanning etter fagbrev - også av de som går i lære (se tabell $6)$.

Interessen for det som foregår i programfagene, varierer fra utdanningsprogram til utdanningsprogram. Elevene på bygg- og anleggsteknikk (BA) og naturbruk (NA) er de som er mest interessert, og $61 \%$ av elevene på BA og $59 \%$ på NA svarer at de er ganske, eller veldig interessert i det som foregår i programfagene. På HO er det bare 35 \% som svarer at de er ganske, eller veldig interessert og på SS er det bare $20 \%$ av elevene som sier at de er ganske, eller veldig interessert.

\section{Kjønnsfordeling blant elever og lærlinger}

Funnene viser at kjønnsfordelingen er skjev og tradisjonell og at det, sett i lys av tidligere forskning, er som det har vært (Vagle \& Møller, 2015), og at kjønnsfordeling var et ikketema blant lærerne. Antall deltakende elever og lærlinger viser at kjønnsfordelingen i tradisjonelle gutte- og jentefag ikke har endret seg nevneverdig siden Kunnskapsløftet ble iverksatt i 2006. Elevutsagn viser at kjønnsfordelingen har stor betydning for mange, spesielt for de som representerer minoriteten. En jente innen elektrofag i Vg1 hevdet at hun "Passer ikke i miljøet", en annen jente innen samme fag syntes det var "Vanskelig å være jente i starten, bedre nå".

\section{Yrkesfaglærernes kompetanse i Vg1}

Elever og lærere er enige om at yrkesfaglig kompetanse (i skole eller bedrift) knyttet til de yrkene elevene utdanner seg til, må være tilgjengelig for elevene, og at lærerne må ha oppdatert kompetanse og oversikt over arbeidslivets kompetansebehov. Undersøkelsen viser at opplæringen ikke differensieres basert på elevenes ulike yrkesmål, og at elevene ønsker større innflytelse. Dette kan tolkes som yrkesfaglærernes behov for kompetanse i yrkesdidaktikk, spesielt yrkesforankring og yrkes-/interessedifferensiering. Lærerne i undersøkelsen har i hovedsak fagbrev og yrkeserfaring, bortsett fra lærerne på SS. En lærer fra elektrofag beskriver utfordringene med manglende lærerkompetanse:

Vi prøver jo å se litt hva en 16 åring synes er artig når vi legger opp aktiviteter i YFF i skolen. Det er jo av og til litt vanskelig i forhold til utstyr og kompetanse da. Det er klart noen elever har jo lyst til å holde på med ting ingen av lærerne har kompetanse $\mathrm{i}$ (Lærer, EL).

Elever og lærere er enige om at yrkesfaglig kompetanse (i skole eller bedrift) knyttet til de yrkene elevene utdanner seg til, må være tilgjengelig for elevene, og at lærerne må ha 
oppdatert kompetanse. Lærerne i undersøkelsen har i hovedsak fagbrev og yrkeserfaring, bortsett fra på SS.

\section{Rekruttering og bortvalg}

Tabell 4 viser at mange elever har planlagt Vg3 påbygg til generell studiekompetanse etter Vg2 allerede i Vg1, og at andelen av elever i vg2 som har planlagt påbygg etter endt skoleår, er lavere enn i Vg1. Mange planlegger også videre utdanning etter fagbrev - også etter at de begynte i lære. Se tabell 4 og 5 .

Tabell 4. Elevenes planer etter $\mathrm{Vg} 2$ i \%

\begin{tabular}{lccc}
\hline & $\begin{array}{l}\text { Begynne som } \\
\text { lærling }\end{array}$ & $\begin{array}{l}\text { Påbygg for å få generell } \\
\text { studiekompetanse }\end{array}$ & $\begin{array}{l}\text { Annet eller } \\
\text { Vet ikke }\end{array}$ \\
\hline Vg1 Elevenes planer etter Vg2 & 61 & 27 & 12 \\
Vg2 elevenes planer etter Vg2 & 52 & 23 & 25 \\
\hline
\end{tabular}

Tabellen nedenfor viser hvor stor andel av Vg2-elevene som planlegger å begynne som lærling og hvor mange som planlegger å ta Vg3 påbygg til generell studiekompetanse etter at de er ferdige med Vg2. Tallene varierer mye fra utdanningsprogram til utdanningsprogram og mellom de ulike lærefagene innenfor utdanningsprogrammene. Tabellen viser at det er flest elever innenfor BA som ønsker å gå i lære (83\%), mens tallene er lavest innenfor medier og kommunikasjon (MK) (2\%) og DH (39\%).

Tabell 5. Vg2-elevenes planer etter at de er ferdig med Vg2

\begin{tabular}{lcccc}
\hline Vg2 & $\begin{array}{l}\text { Antall Vg2-elever som } \\
\text { har svart }\end{array}$ & $\begin{array}{l}\text { \% elever som } \\
\text { vil bli lærling }\end{array}$ & $\begin{array}{c}\text { \% elever som vil } \\
\text { ta Vg3 påbygg }\end{array}$ & $\begin{array}{c}\text { \% elever som har svart } \\
\text { Annet eller Vet ikke }\end{array}$ \\
\hline BA & 100 & 83 & 8 & 9 \\
DH & 84 & 39 & 27 & 34 \\
EL & 227 & 52 & 11 & 37 \\
HO & 291 & 40 & 40 & 20 \\
MK & 50 & 2 & 50 & 48 \\
NA & 20 & 55 & 5 & 40 \\
RM & 33 & 67 & 12 & 21 \\
SS & 115 & 53 & 30 & 17 \\
TIP & 258 & 68 & 11 & 21 \\
\hline
\end{tabular}


Tabell nr. 6 viser at halvparten av lærlingene har planer om å ta videre utdanning etter at de har tatt fag-/svennebrev. Det kan bety at bortvalget av fagarbeid er minst like stort som bortvalget fra yrkesutdanningen. Statistikk viser også at det er vanskelig å få fulltidsjobb som helsefagarbeider, noe som kan gi en forklaring på at 70\% av lærlingene innen helsefagarbeid allerede før de tar fagprøve, har planer om å utdanne seg videre (Meld. St. 20 (2012-2013). Men hva er årsaken til at over 50\% av elektriker- og dataelektronikerlærlingene, over $60 \%$ av lærlingene i barne- og ungdomsarbeid og over $75 \%$ av industrimekanikerlærlingene har slike planer?

Tabell 6: Laerlingenes planer om videre utdanning etter fag-/svennebrev

\begin{tabular}{|c|c|c|c|c|}
\hline Larefag & $\begin{array}{l}\text { Antall } \\
\text { lærlinger }\end{array}$ & $\begin{array}{l}\text { \% elever som har } \\
\text { svart JA }\end{array}$ & $\begin{array}{l}\text { \% elever som } \\
\text { har svart NEI }\end{array}$ & $\begin{array}{l}\text { \% elever som ikke } \\
\text { har svart eller } \\
\text { som har svart Vet } \\
\text { ikke }\end{array}$ \\
\hline $\begin{array}{l}\text { Barne- og } \\
\text { ungdomsarbeider }\end{array}$ & 73 & 63 & 32 & 5 \\
\hline Bilfaget - lette kjøretøy & 25 & 40 & 48 & 12 \\
\hline Dataelektroniker & 9 & 56 & 33 & 11 \\
\hline Elektriker & 37 & 54 & 43 & 3 \\
\hline Frisør & 21 & 19 & 67 & 14 \\
\hline Helsefagarbeider & 64 & 70 & 22 & 8 \\
\hline Industrimekaniker & 16 & 75 & 25 & 0 \\
\hline Kokkfaget & 14 & 43 & 57 & 0 \\
\hline Logistikkfaget & 10 & 30 & 70 & 0 \\
\hline Tømrerfaget & 30 & 37 & 47 & 16 \\
\hline
\end{tabular}




\section{Drøfting}

Drøftingen er strukturert under overskrifter som er basert på fokusområdene i studien og er knyttet mot artikkelens problemstilling: Hvordan fungerer Vg1 yrkesfaglig utdanningsprogram for elever med ulike yrkesvalg? Funnene relateres avslutningsvis til pågående endringer i yrkesopplæringen.

\section{Tilpasset innhold og Vg1-opplæringens relevans for elever med ulike yrkesplaner}

Elevene har til dels store forventninger, også når det gjelder faglig utbytte av opplæringen i Vg1 (figur 3). For ca. $60 \%$ av elevene er disse forventningene knyttet til å lære et spesifikt yrke, mens elever i gruppen som ikke hadde bestemt seg for et spesifikt yrke, hadde forventninger om at opplæringen skulle være interessant, at de skulle lære noe nytt og om å lære et yrke.

Når vi ser på elevenes og lærlingenes beskrivelse av innholdet, synes det ikke umiddelbart å være tilpasset til elevenes læreforutsetninger i form av interesser og yrkesplaner eller være relevant for det yrket elevene utdanner seg til. Vi kan imidlertid se mulighetene for at forklaring av overføringsverdi kan synliggjøre en nytteverdi uten at elevene uttrykker forståelse for det. Årsaken til den manglende relevansen kan dermed forklares i minst to perspektiver: 1) opplæringen er ikke relevant for yrkene, eller 2) opplæringen er relevant, men elevene uttrykker ikke forståelse for overføringsverdien. Funnene viser ikke en konsistent sammenheng mellom bruk av bedriftene som læringsarena og elevenes/lærlingenes opplevelse av opplæringens relevans. Det betyr at opplæring både i bedrift og i skole kan oppleves lite relevant betinget av hva elevene jobber med og lærer i bedrift/offentlig virksomhet. Basert på Illeris’ drivkraftdimensjon (figur 1), Deci og Ryans og Deweys demokratiperspektiv og analyse av betydningen av indre motivasjon og opplevelse av mening for den enkelte lærende, er manglende opplevelse av relevans og mening en utfordring det må tas tak i for å sikre kvalitet i yrkesopplæringen.

Ca. $60 \%$ av elevene i vår undersøkelse hadde behov for å lære et spesifikt yrke og opplevde at det de lærte i Vg1, ikke var relevant for yrkene de utdanner seg til. Det er ifølge både Deci og Ryan (2000) og Illeris (2012) kritisk med tanke på motivasjon og drivkraft for læring. Elevens behov samsvarer dermed med sentral teori om motivasjon og læring. Funnene viser at det er stor forskjell på hvor godt Vg1-opplæringen fungerer som del av ulike 
fagopplæringsløp (se tabell 1). For de store lærefagene i BA, EL og RM, henholdsvis tømrer, elektriker og kokk, synes opplæringens innhold å passe til elevenes yrkesvalg, da opplæringen i stor grad handler om disse lærefagene. På disse utdanningsprogrammene har mange av yrkesfaglærerne faglig kompetanse innenfor de sammen lærefagene. Det største lærefaget på DH, frisørfaget, ivaretas ikke på samme måte som de store lærefagene i de andre utdanningsprogrammene. Dette kan ha sammenheng med at det er få lærere med yrkesfagligeller frisørfaglig bakgrunn som underviser på Vg1 DH. (Kunnskapsdepartementet 2006, Meld. St. 20. (2012-2013)). Dette krever at lærere i Vg1 og brede Vg2 har yrkesdidaktisk og oppdatert yrkesfaglig kompetanse i eget yrkesfag og i andre yrkesfag i sitt utdanningsprogram, som gjør yrkesdifferensiering og eksemplifisering av innholdet relatert til elevenes ulike yrkesønsker, mulig. Mange av lærerne i vår undersøkelse opplevde behov for kompetanseheving både innen yrkesfag og yrkesdidaktikk, samtidig som elevene uttrykte at det var viktig med gode lærere som kunne faget de utdannet seg til. Dette kompetansebehovet er også dokumentert i Fafo's rapport 2017:11, Yrkesfaglærernes kompetanse (Aspøy, Skinnarland \& Tønder, 2017)

Av de elevene som ikke hadde bestemt seg for et spesifikt yrke, hadde mange studiespesialisering som førstevalg og dermed ikke behov for at opplæringen skal være relevant for et spesifikt yrke. Prosentandelen av elever som hadde SSP som førstevalg, var for eksempel 8 på SS og 7,4 på TIP og DH. På tvers av utdanningsprogram var det 4\% som ønsket seg SSP. Dette kan kanskje forklare noen av elevenes manglende motivasjon for yrkesfagene i utdanningsprogrammet de har valgt.

\section{Demokrati, elevmedvirkning og elevenes innflytelse på eget læringsarbeid}

Funnene viser at elevene i liten grad medvirker i utforming av eget læringsarbeid på en måte som har betydning for deres opplevelse av mening og yrkesrelevans. Elever og lærere synes å ha til dels ulik forståelse av innholdet i sentrale begreper i yrkesopplæringen, som demokrati, elevmedvirkning og elevinnflytelse. Eksempelvis synes både elever og lærere å forstå føringene knyttet til elevmedvirkning og demokrati som styringsform mer enn som læringsstrategi. De knytter i stor grad disse begrepene til klasse- og elevrådsarbeid. For å oppnå en tilpasset opplæring som er meningsfull og relevant for alle elevene uavhengig av utdanningsplan, må imidlertid begrepene elevmedvirkning og demokrati knyttes til læring og gi rom for alle (Hansen \& Haaland, 2012). Både Illeris' (2012) drivkraftsdimensjon, eller motivasjon for læring, og Deci og Ryans (2000) teori rundt behovet for indre motivasjon, 
støtter nasjonale føringer i opplæringen og er avgjørende for elevenes motivasjon og kompetanseutvikling.

\section{Yrkesretting og sammenheng mellom nivåene i yrkesopplæringen}

Studien viser manglende sammenheng mellom de ulike nivåene i yrkesopplæringen. I mange av lærefagene opplever elevene og lærlingene at innholdet i opplæringen ikke passer til den yrkeskompetansen de sikter mot. Det er interessant å registrere at de nasjonale føringene i stor grad samsvarer med elevenes, lærlingenes og lærernes behov i yrkesopplæringen, mens opplæringen i de yrkesfaglige utdanningsprogrammene ikke fungerer i samsvarer med disse. Årsaken til dette kan knyttes til rammer som manglende tilgjengelig utstyr og lærerkompetanse. Mange av lærerne henviser til «forbud» mot bruk av arbeidslivet som læringsarena, spesielt i Vg1, mens mange opplever at arbeidslivet i liten grad er åpent for å ta imot elever. Lærerne, for eksempel på Vg1 SS, opplevde å ha smal kompetanse å spille på i forhold til elevenes ulike yrkesvalg. Disse lærerne hadde i stor grad kompetanse knyttet til økonomi og ledelse og savnet for eksempel tilgjengelig kompetanse innen logistikk- og yrkessjåførfaget. Kanskje burde bred kompetanse i lærerteamene prioriteres der det er mulig i stedet for at to eller flere lærere i teamene har samme fagbakgrunn?

Mangel på handlingsrom og felles innhold i yrkene som rekrutterer fra samme utdanningsprogram, er en annen faktor som kan ha betydning for hvilke yrkesfag som ivaretas i Vg1. Det er for eksempel manglende rom i læreplanen for Vg1 EL for å sikre yrkesrelevant innhold i opplæringen for dataelektronikere. Læreplanen for Vg1 RM har stort handlingsrom for å tilpasse opplæringen til elevenes yrkesplaner, mens elever og lærlinger i denne studien viser at Vg1- opplæringen ikke oppleves relevant for konditorfaget.

\section{Konklusjon og framtidens yrkesopplæring i skole}

Mangel på yrkesrelevans og elevenes opplevelse av mening er ifølge denne studien hovedutfordringen i Vg1 og brede Vg2 i yrkesopplæringen. Demotivasjon og mulig frafall kan derfor være en naturlig konsekvens av dagens yrkesopplæring i skole for mange elever (Deci \& Ryan 2000; Illeris 2012; Dewey 2000). Funnene viser at det må gjøres omfattende endringer på både innhold og arbeidsmåter for at opplæringen skal være god for elever med ulike yrker som mål. Behovet for interesse- og yrkesdifferensiering i opplæringen er åpenbar. 
For noen av yrkene/lærefagene synes opplæringen i Vg1 å treffe dårlig, og elevene opplever liten grad av relevans. Selv om mange elever kommer til å endre valg av yrkesmål i løpet av de nærmeste årene, er det tydelig at det er «dagens» mål, interesser og forventninger som skaper drivkraft og motivasjon for læring (Illeris, 2012; Dewey, 2000; Deci \& Ryan, 2000). Det tar tid å lære seg fagarbeid, og manglende tid til å øve på yrkesoppgaver i Vg1 og brede Vg2 kan få dramatiske følger for kvalitet på fagarbeid, yrkeskompetanse i framtiden, samt utvikling av yrkesidentitet og yrkesstolthet. Opplevelsen av relevans er ifølge våre funn og aktuell motivasjons- og læringsteori, avgjørende for læringsarbeidet.

At opplæringen skal være yrkesrelevant og tilpasses elevenes interesser og eventuelle yrkesplaner, er ikke klart formulert i de fleste fagspesifikke læreplanene for Vg1. Dette bør derfor tydeliggjøres. Innholdet i Vg1 må kanskje endres, eller det må kanskje fokuseres mer på å forklare innholdet i opplæringen relatert til elevenes ulike yrkesvalg?

Funnene viser samsvar mellom nasjonale føringer, aktuell lærings- og motivasjonsteori og elevenes kvalitetskriterier. Samtidig viser funnene manglende samsvar mellom de nasjonale føringene og måten opplæringen gjennomføres på i Vg1, noe som kan tyde på at LK06 kanskje ikke helt og fullt er innført ved Vg1 i de yrkesfaglige utdanningsprogrammene. Det kan bety at evalueringen av LK06 er basert på en annen praksis enn den som er beskrevet i læreplanverket med tilhørende grunnlagsdokumenter.

\section{Ny struktur i framtidens yrkesopplæring?}

Kunnskapsdepartementet la våren 2017 fram forslag til ny struktur i yrkesopplæringen (KD, 2017). Funnene i studien vår gir godt grunnlag for vurdering av behov knyttet til framtidig struktur og innhold i yrkesopplæringen. Grunnlaget for departementets forslag er basert på behovet for å utvikle en yrkesopplæring som er meningsfull og yrkesrelevant for elever med ulike yrkesplaner, konsistent, som her betyr sammenhengende fra begynnelsen i Vg1 og den fag-/svenneprøven elevene skal ta, samt barekraftig ${ }^{4}$, som blant annet handler om at det skal være tilgjengelige læreplasser og behov for lærefaget i et samfunnsperspektiv (Utdanningsdirektoratet, 2017a). Forslaget er basert på Stortingsmelding 20 (2012-2013), diverse forskningsrapporter og statistikk, rapport fra de fem yrkesfaglige utvalgene (Udir, 2016b), utviklingsredegjørelsene fra de faglige rådene (Udir., 2016b) og

\footnotetext{
${ }^{4}$ Foredrag av Dagfinn Hertzberg, Kunnskapsdepartementet, ved Høgskolen i Oslo og Akershus 16.mai 2017
} 
utdanningsdirektoratets anbefalinger i dokumentet Gjennomgang av det yrkesfaglige utdanningstilbudet (Utdanningsdirektoratet, 2016b).

Ideen er at en mer relevant struktur skal være med på å gjøre fagopplæringen mer attraktiv i arbeidslivet (Meld. St. 20 (2012-2013). Endringene i strukturen skal bidra til bedre samsvar med arbeids- og samfunnslivets behov for faglært kompetanse gjennom en mer relevant opplæring rettet konkret mot et yrke og grupper av yrker. Målet er å utvikle et konsistent opplæringsløp fra Vg1 til Vg3 med god progresjon fram til lærefag og yrker (Meld. St. 20 (2012-2013). Tanken er at den nye strukturen skal gi mer motiverte elever, et godt grunnlag for fagopplæring $\mathrm{i}$ hele landet og at flere bedrifter i større grad enn tidligere skal benytte lærlingeordningen for å rekruttere framtidig arbeidskraft. Våre funn viser behov for en endring i tråd med ideen bak endring av strukturen. Mange lærlinger i ulike lærefag har erfart at opplæringen i Vg1- og Vg2 ikke er relevant for det yrket de utdanner seg til. Funnene viser at innholdet i opplæringen ikke er tilpasset elevenes yrkesvalg og forventninger. Det kan resultere i demotivasjon, som en naturlig konsekvens sett i lys av Deci og Ryan (2000) sin motivasjonsteori og drivkraftsdimensjonen i Illeris (2012) sin læringsteori. I følge Illeriss (2012) er det gjennom innholdsdimensjonen, eller arbeidet med relevante og selvvalgte yrkesoppgaver, at elevene utvikler innsikt, forståelse og evner - skaper mening, og øver opp mestring. Handlingsrommet i læreplanene brukes i liten grad som grunnlag for interesse-/og yrkesdifferensiering, noe som kan forklares gjennom manglende synliggjøring og føringer for bruk av dette handlingsrommet i læreplanene for å sikre relevans.

Siden opplæringen i Vg1 opplevdes lite eller ikke relevant for mange av yrkene som lærlingene i undersøkelsen utdannet seg til, bør årsaken til dette studeres nærmere før framtidig struktur bestemmes. Det bør kanskje sikres at yrker med stor grad av fellestrekk settes sammen i hvert Vg1 og brede Vg2. Forslaget fra KD vil ikke nødvendigvis bidra til en forbedring av yrkesopplæringen. Forslaget resulterer i at Vg1 TIP blir like bredt som i dag, da noen lærefag foreslås nedlagt, samtidig som departementet foreslår at nye lærefag, som logistikk og yrkessjåfør, skal flyttes fra SS til TIP. Utfordringene med å oppnå yrkesrelevans vil da være minst like store i ny struktur. Vg1 DH blir i KDs forslag til struktur smalere, samtidig som kurvmaker, som har lite eller ingenting til felles med andre BA-fag, legges til BA og resulterer i større bredde og forskjell på fagene i Vg1 BA. Oppdelingen i Vg2 matfag til flere små Vg2-løp vil kanskje redusere bærekraften, i strid med grunnlaget fra KD (2017b). 


\section{Rekruttering til yrkesfag, frafall og bortvalg}

Resultatet av denne studien viser store utfordringer knyttet til å oppnå yrkesrelevans i Vg1 og i brede Vg2, noe som fører til laber interesse for opplæringen. Dette kan resultere i negative konsekvenser for framtidig kvalitet på fagarbeid, yrkes- og yrkesfaglærerkompetanse, samt yrkesstolthet.

Funnene viser at bortvalget er stort hele veien i utdanningsløpet. Mange elever hadde ikke kommet inn på førstevalget sitt. Mange av disse ønsket seg i utgangspunktet studiespesialisering, og mange elever valgte "påbygg" etter Vg2. Bortvalget av fagarbeid er også stort blant lærlingene, hvor ca. halvparten allerede i læretiden hadde planer om videre utdanning etter at de hadde tatt fag-/svennebrev. Dette viser et stort behov for tiltak som kan gjøre yrkesopplæringen mer attraktiv og et arbeidsliv hvor fagarbeidere får bruke sin kompetanse i helhetlige arbeidsoppgaver.

I noen av fagene er utfordringer synlige i mediedebatten, som for eksempel i byggebransjen og i restaurantnæringen, hvor det tilsettes mange uten fagbrev som gjør samme jobben som de med fagbrev (Bals, 2017). Utfordringer i byggebransjen er også knyttet til språk og kommunikasjon, fordi det etterhvert er flest minoritetsspråklige på mange byggeplasser. Byggebransjen har også fått tilbake et formannsnivå, noe som kan gi mindre muligheter for helhetlig arbeid og ansvar og dermed mindre utfordringer og mening $\mathrm{i}$ arbeidet som fagarbeider (Bals, 2017). Funnene viser også at kjønnsfordelingen fremdeles er skjev i de ulike utdanningsprogrammene på samme måte som i arbeidslivet (Vagle \& Møller, 2015).

Politikerne har de siste årene vært opptatt av å "framsnakke" yrkesopplæringen og har ved ulike anledninger presisert at det er attraktivt å være fagarbeider. Våre funn viser kanskje det motsatte, noe som sannsynliggjør at andre tiltak enn framsnakking må iverksettes for at fagarbeid skal bli attraktivt sett fra lærlingers og fagarbeideres ståsted? Statistikk fra SSB (Statistisk sentralbyrå, 2014) viser at rekrutteringen til yrkesfag er til dels kritisk lav sammenlignet med samfunnets framtidige kompetansebehov. Funnene viser også at mange av elevene på yrkesfag hadde SSP som førstevalg, mange har planer om påbygg etter Vg2, og mange har planer om videre utdanning etter fagbrev. Disse funnene viser at den reelle rekrutteringen til yrkesfaglig utdanning og framtidig yrke som fagarbeider er enda lavere enn det statistikkene viser. En annen årsak til elevenes manglende opplevelse av mening og 
muligens frafall, er at mange elever har søkt et annet utdanningsprogram enn det de kom inn på..

\section{Lærernes og lærerteamenes kompetanse har stor betydning for å oppnå yrkesrelevans}

Manglende relevans kan også være et resultat av lærernes behov for kompetanseutvikling sammen med manglende tilbud for å lede læringsarbeid i tråd med læreplanverket i LK06.

Elevene og lærlingene i undersøkelsen mener gode lærere, som kan faget sitt og det yrkesfaget elevene og lærlingene utdanner seg til, er viktig. Sett i sammenheng med lærernes uttalelser om eget kompetansebehov, omfatter dette i tillegg til oppdatert yrkesfaglig kompetanse, kompetanse i yrkesdidaktikk, yrkes-/interessedifferensiering og tilpasset opplæring til elever med ulike utdanningsmål. Lærerne i undersøkelsen var også opptatt av at det var viktig å ha kompetanse innenfor elevenes valgte yrkesområder tilgjengelig, ved skolen og/eller i arbeidslivet. Mange av lærerne opplevde at fagkompetansen i teamene var smal, og at det derfor var vanskelig å eksemplifisere og legge til rette for læringsarbeid i tråd med elevenes yrkesvalg. Lærerne ønsker mulighet til å utvikle sin kompetanse som gjør dem i stand til å håndtere det mangfoldet av behov elevene har for å lære ulike yrker. Funnene gir grunnlag for vurdering av yrkesfaglærernes kompetansebehov i en ny struktur. De gir derfor også grunnlag for vurdering av behov for etter- og videreutdanning for yrkesfaglærere, samt vektlegging av innhold og arbeidsmåter i yrkesfaglærerutdanningene.

Kunnskapsdepartementets satsing på kompetanseheving for yrkesfaglærere;

Yrkesfaglærerløftet, kan derfor være viktig over tid, sett i lys av funnene i denne studien. Yrkesfaglærerne beskriver behov for både yrkesfaglig og yrkesdidaktisk kompetanse for å håndtere utfordringene $\mathrm{i} V \mathrm{~g} 1 \mathrm{og}$ brede $\mathrm{Vg}$ 2. 


\section{Litteratur}

Aspøy Mogstad, T. Skinnarland, S. \& Tønder Hagen, A. (2017). Yrkesfaglcerernes kompetanse. Fafo-rapport 2017:11. Oslo: Fafo

Bals, J. (2017). Hvem skal bygge landet? Oslo: Cappelen Damm AS.

Dahl, T., Buland, T., Mordal, S. \& Aaslid, B. E. (2012). På de samme stier som før: Kunnskapsløftet i fag- og yrkesopplaeringen. Trondheim: SINTEF.

Dahlback, J., Hansen, K., Haaland, G. \& Sylte, A. L. (2011). Yrkesdidaktisk kunnskapsutvikling og implementering av nye loereplaner - Veien til yrkesrelevant opploering fra første dag $i \mathrm{Vgl}$. Oslo: Høgskolen i Akershus.

Dale, E. L. \& Wærness, J. I. (2003). Tilpasset opplcering og inkludering i skolefaglige loereprosesser. Lastet ned 23.08.2017 http://www.bestilling.utdanningsdirektoratet.no/Bestillingstorg/PDF/Kompetansefor tilpasset opplaring.pdf

Deci, E. L. \& Ryan R. M. (2000). The 'what' and 'why' of goal pursuits: Human needs and the self-determination of behavior. Psychological Inquiry, 11, 227-268.

Deichman-Sørensen, T. (2015). "Lik kvalitet" - fra yrkesstyring til ytrestyring, fra praksisfellesskap til fellesmarked. I: O. Eikeland, H. Hiim \& E. Schwencke (red), Yrkespedagogiske perspektiver. (Kap. 10. s. 219-270.) Oslo: Gyldendal Akademisk.

Dewey, J. (2000). Utdanning til demokrati - barnet, skolen og den nye pedagogikk - John Dewey $i$ utvalg. S. Vaage (Red.). Oslo: Abstrakt forlag.

Dewey, J. (1910). How We Think. Boston: D.C. Heath.

Hansen, K. H. (2017). Hva er yrkesdidaktikk etter Kunnskapsløftet? Scandinavian Journal of Vocations in Development. Vol 2. S. 1-25.

Hansen, K. \& Haaland, G. (2012). Demokratisk klasseledelse i yrkesfag. I: G. Engvik, T. A. Hestbek, T. L. Hoel \& M.B. Postholm (Red.), Klasseledelse - for elevenes laering (s.67-84). Trondheim: Akademika forlag.

Hansen, K. \& Haaland, G. (2015a). Utfordringer i norsk yrkesopplæring. I: K. Hansen, T.L. Hoel \& G. Haaland (Red.): Tett på yrkesopplaering (s.19-46). Fagbokforlaget: Bergen.

Hansen, K. \& Haaland, G. (2015b). Engasjerte og interesserte elever gjennom en meningsfull, helhetlig og relevant yrkesopplæring. I: K. Hansen, T.L. Hoel \& G. Haaland (Red): Tett på yrkesopplaering. (s. 157-177). Fagbokforlaget: Bergen.

Hiim, H. (2013). Praksisbasert yrkesutdanning - Hvordan utvikle relevant yrkesutdanning for elever og arbeidsliv? Oslo: Gyldendal Akademisk. 
Illeris, K. (1999). Erfaringspædagogik og «experiential learning». Om erfaringspædagogikkens grundlag og betingelser i dag. I: Nordisk Pedagogik, 19(1), $1-19$.

Illeris, K. (2012). Loering. Oslo: Gyldendal Akademisk.

Johannessen, A., Tufte, P. A. \& Christoffersen, L. (2016). Introduksjon til samfunnsvitenskapelig metode (4. utg.). Oslo: Abstrakt.

Kjeldstadli, K. (1999). Fortida er ikke hva den en gang var: en innføring i historiefaget. (2. utgave). Oslo: Universitetsforlaget.

Kunnskapsdepartementet (2006). Laereplanverket for Kunnskapsløftet (LK06). Oslo: Departementet. https://www.udir.no/globalassets/upload/larerplaner/fastsatte lareplaner for kunnsk apsloeftet/prinsipper $1 \mathrm{k} 06 . \mathrm{pdf}$

Kunnskapsdepartementet (2017b). Forslag til endringer i den yrkesfaglige tilbudsstrukturen. Oslo: Departementet.

Kvale, S. \& Brinkmann, S. (2017). Det kvalitative forskningsintervju. Gyldendal Akademisk: Oslo.

Malterud, K. (2006). Kvalitative metoder i medisinsk forskning. Oslo: Universitetsforlaget.

Meld. St. 18 (2012-2013). (2013). Lange linjer - kunnskap gir muligheter. Oslo: Kunnskapsdepartementet.

Meld. St. 20 (2012-2013). (2013). På rett vei-Kvalitet og mangfold i fellesskolen. Oslo: Kunnskapsdepartementet.

Meld. St. 28 (2015-2016). (2016). Fag-Fordypning - Forståelse. En fornyelse av Kunnskapsløftet. Oslo: Kunnskapsdepartementet.

Meld. St. 30 (2003 - 2004). Kultur for loering. Oslo: Utdannings- og forskningsdepartementet.

Nilsen, S. E. \& Haaland, G. (2013). Laring gjennom praksis: innhold og arbeidsmåter $i$ yrkesopplaeringen: en grunnbok i yrkesdidaktikk. Oslo: Pedlex.

NOU 2015:8. Fremtidens skole - Fornyelse av fag og kompetanser. Oslo: Kunnskapsdepartementet.

Postholm, M. B. (2010). Kvalitativ metode. En innføring med fokus på fenomenologi, etnografi og casusstudier. (2. utg.). Oslo: Universitetsforlaget.

Postholm, M. B. \& Jacobsen, D. I. (2012). Laereren med forskerblikk. En innføringsbok $i$ vitenskapelig metode for loererstudenter. Kristiansand: Høyskoleforlaget. 
Skaalvik, E. M. \& Skaalvik, S. (2013). Skolen som lceringsarena. Selvoppfatning, motivasjon og laering. (2. utg.). Oslo: Universitetsforlaget.

Statistisk Sentralbyrå (2017). Lastet ned 27.08.2017. Gjennomføring i videregående opplæring. https://www.ssb.no/vgogjen

Statistisk Sentralbyrå (2014). Lastet ned 29.06.2017. Framskrivinger av befolkning og arbeidsstyrke etter utdanning med alternative forutsetninger for innvandring. https://www.ssb.no/arbeid-og-lonn/artikler-og-publikasjoner/framskrivinger-avbefolkning-og-arbeidsstyrke-etter-utdanning-med-alternative-forutsetninger-forinnvandring.

Sund, G. Haaland (2005). Forskjellighet og mangfold - muligheter eller begrensninger for individ og arbeidsplass, Et aksjonsforskningsprosjekt med studier av læring i daglig arbeid, gjennom medvirkning, demokratiske prosesser og interessedifferesiering. Ph.d.-avhandling, Roskilde Universitetssenter.

Thagaard, T. (2009). Systematikk og innlevelse. En innføring i kvalitativ metode. Bergen: Fagbokforlaget.

Utdanningsdirektoratet, (2006). Lastet ned 25.11.2017. https://www.udir.no/laring-ogtrivsel/lareplanverket/prinsipper-for-opplaringen $2 /$

Utdanningsdirektoratet (2016a). Yrkesfaglig fordypning - YFF (tidligere prosjekt til fordypning, PTF)Lastet ned 29.06.2017. https://www.bing.com/search?q=forskrift+yrkesfaglig+fordyping\&FORM=EDGEN $\underline{A}$

Utdanningsdirektoratet (2016b). Gjennomgang av det yrkesfaglige utdanningstilbudet. Oslo: Udir. Hentet 15.08.2017: https://www.udir.no/laring-ogtrivsel/lareplanverket/forsok-og-pagaende-arbeid/gjennomgang-av-det-yrkesfagligeutdanningstilbudet/

Utdanningsdirektoratet (2017a). Høring 131. Høring av endringer i den yrkesfaglige tilbudsstrukturen. Oslo: Udir. Lastet ned 14.08.2017: https://hoering.udir.no/Hoering/131

Utdanningsdirektoratet (2017b). Lastet ned 8.11.2017. Generell del av læreplanen. https://www.udir.no/laring-og-trivsel/lareplanverket/generell-del-av-lareplanen/

Vagle, I. \& Møller, E. (2015). Kjønn på dagsorden gjennom to-tre-og firepartssamarbeidet det yrkesfaglige feltet. Ph.d.-avhandling. Roskilde: Roskilde Universitet.

Vogt, K. C. (2017). Vår utålmodighet med ungdom. I: Tidsskrift for samfunnsforskning, (58), $1,105-119$.

Aarkrog, V. \& Bang, S. W. (2013). Resultater af evalueringer af Kunnskapsløftet: En syntese. Aarhus: Aarhus Universitet. 